\title{
Foreign Working Women and Child-Rearing
}

\section{Lauren Landsberry \\ Nagoya College}

\section{Tenesha Kanai}

Osaka City Board of Education

\section{Reference Data:}

Landsberry, L. \& Kanai, T. (2019). Foreign working women and child-rearing. In P. Clements, A. Krause, \& P. Bennett (Eds.), Diversity and inclusion. Tokyo: JALT.

Most foreign women living and working in Japan, while raising multicultural children, may find it challenging to manage their roles as caregivers and cultural and linguistic transmitters while pursuing their professional goals. In a patriarchal society, where more old-fashioned expectations of women prevail, foreign working mothers must endeavor to navigate their way not only culturally and linguistically but also professionally. The aim of this study is to explore foreign working mothers' efforts across their multiple roles in Japan. Data obtained via questionnaires consisting of qualitative and quantitative items from working foreign women practicing multicultural child-rearing were scrutinized and statistically analyzed to provide a rich understanding of the participants' experiences. Findings outline the challenges they face in tending to their roles and responsibilities and the strategies they adopt to deal with the challenges experienced. The authors further canvass and discuss the societal and familial factors that have contributed to their journeys.

日本在住で仕事をしている多くの外国人女性は、キャリアを追求しつつ、多文化の子育てをするうえで、子育てと自らの文 化および言語の伝達という役割を困難に感しているであろう。家父長制の社会においては、女性に対して、より保守的な考え が流布しており、仕事を持つ外国人女性は、文化的言語的観点からだけではなく職業的観点からも自身の進路を切り開く努力 をしなければならない。この研究目的は、日本で子供を持つ外国人女性の多文化的役割への取り組みを調査することである。 仕事を持つ外国人女性の多文化的子育てについての量的、質的質問項目から構成されたアンケートを用いてデータ取集を 行いデータを精査し統計分析を行つた。その結果、被験者の経験について深い理解に行き着いた。彼女達の役割や責任に おいて直面した課題とその課題への対処法を、研究結果として概説する。彼女らの道程に奇与した社会的家族的要因につい ても、詳しく調査し議論する。 $\mathrm{n}$ Japan, the number of women participating in the labour force has increased over the last decade. In fact, working women between the ages of 30 and 34 rose to $75.2 \%$ in 2017, a 50\% increase from three decades ago (Goto, 2018). One factor contributing to the increase in women's participation in the workforce is Japanese Prime Minister Shinzo Abe's structural reform labelled "Womenomics," aimed at encouraging participation and the advancement of women in the labour force. Strategies of Womenomics include the expansion of childcare benefits for women, tax breaks for double income families, and encouragement for companies to promote women more and provide data on the advancement of women (Chotani, 2017). All of these may have contributed to the increase in female labour participation.

Initiatives such as these demonstrate that modern Japan is working towards facilitating female employment, however Japanese women continue to struggle with combining work and child-rearing. A reported $70 \%$ of women quit their jobs after childbirth, compared to one third in the United States (Wingfield-Hayes, 2013; Yu, 2009). Many women cite reasons such as the chronic shortage of childcare, Japan's culture of long working hours, the low participation of fathers in child-rearing, and harassment from employers who would prefer that women quit their jobs because of the presumption that they cannot balance child-rearing and work responsibilities (Holloway \& Nagase, 2014; Koide, 2015).

These issues are exacerbated for foreign women who choose to work while participating in multicultural child-rearing, as their roles as caregivers as well as cultural and linguistic transmitters may be intensified as they navigate a society where oldfashioned attitudes towards women prevail. With a current figure of 1.3 million foreign women in Japan (E-Stat, 2017), it is important to understand the experiences of those who attempt to combine work and child-rearing. This study therefore is aimed at contributing to the literature on maternal employment, providing the results of surveys completed by 145 working non-Japanese women in Japan. 
Generally, combining child-rearing and work is challenging for women in both developed and developing countries, as they continue to bear the heavier burden of childrearing compared to their male counterparts. However, Japan has unique challenges as a developed country, trailing behind the likes of Germany and the U.S.A., with low female participation in the labour force (Lewis, 2015). Rooted in Confucianism, Japan places a high degree of importance on the family for a stable society and differentiation between the sexes is more clearly defined (Koide, 2015).

In postwar Japan, the move to an industrial society and the rise in salarymen fathers who exchanged long working hours, business trips, and transfers for lifetime employment has meant that the full burden of child-rearing is generally borne by the mother (Yashiro, 2009). Women are expected to devote themselves to child-rearing, their husbands, and sometimes their aging parents and in-laws. Through the media, the government introduced policies and commissioned several reports to promote women's roles as housewives and the importance of forming a maternal bond during the first 3 years of their children's lives (Holloway \& Nagase, 2014). Women who choose to work deal with not only the stress of juggling work and childcare commitments but also the disapproving attitudes of extended family, neighbours, and sometimes even their own colleagues (Jolivet, 1997).

Even in a high-status career such as a physician, many women leave their position within the first 9 years after graduation; childbirth and child-rearing are the main factors. In a study of 249 physician mothers in Japan, authors Yamazaki, Kozono, Moir, and Maru (2011) described women facing challenges associated with Japanese society, family responsibilities, and their work environment. Women in the study believed that the traditional role fostered by Japanese society encourages discrimination from their male counterparts and that this creates stress at work. For many women in Japan, the most accepted pattern is to enter the full-time labour force on completion of school, leave at marriage or the birth of the first child, and return, usually as a part-time worker, when child-rearing responsibilities lessen (Holloway \& Nagase, 2014; Yamazaki et al. 2011; Zhou, 2014).

For some foreign women from western cultures such as North America, Oceania, the United Kingdom, and Europe, the expectations and status of women in Japanese society will come as a shock, and child-rearing practices may be different from what they are used to. Many of these women do not have experience raising multicultural and bilingual children, and although the foreign population and number of mixed-race Japanese children have increased, diversity and multiculturalism are yet to be fully understood by many in Japan. Kuramoto, Koide, Yoshida, and Ogawa's (2017) research into multicultural child-rearing in Japan revealed that parents encountered many difficulties and challenges related to educational issues and cultural differences in parenting. Parents in the study believed that due to the ethnic homogeneity of Japanese society, there is an inadequate understanding of multicultural families and multicultural children. Some children are bullied due to appearance, and there is a dearth of resources for bilingual education, all of which create barriers for many parents.

Kuramoto et al. (2017) further explained that working mothers also believed that the Japanese school system was not designed to accommodate working women, especially with children of kindergarten and elementary-school age, where an active role in the Parent Teacher Association (PTA) is required. It is quite normal for every parent to hold a leadership position in the PTA at least once when their child is in grades 1 through 6 (Koide, 2015). It may be difficult for a foreign mother who has a full-time job and lacks Japanese-speaking skills to fulfil leadership positions that require an ability to speak Japanese. In addition, obtaining time off work to attend school events may be impossible as Japan is known for its inflexible working conditions and long working hours (Lane, 2017).

As mentioned earlier, the shortage of childcare facilities is a problem for parents, and this contributes to some women leaving the workforce after childbirth. As of October 1 , 2017, a reported 55,433 children were on waiting lists for nurseries (Jiji Press, 2018). For the foreign working mother, this may be quite difficult, especially if she has no relatives or parents living nearby whom she can ask for support. Koide (2015), in her research on the work-life balance of Japanese and foreign women in Japan, reported foreign women citing the lack of childcare as a significant concern when working towards achieving that balance. In addition to the lack of childcare, foreign mothers in Koide's study described the Japanese school calendar as having an irregular schedule, which is a major challenge for working mothers. The literature on foreign women and child-rearing shows that they feel pressure as they must thrive and navigate their multiple roles in another culture, while also maintaining their birth country's culture and their own professional aspirations.

\section{The Study and Research Questions}

The study was aimed at exploring the challenges and difficulties facing foreign working women whilst raising multicultural children and determining how they dealt with these challenges. The following research questions were focused on:

RQ1. What are the challenges and difficulties that foreign working mothers face in Japan? 
RQ2. How do they deal with these challenges and difficulties?

RQ3. What are their future aspirations for Japan?

\section{Methods}

\section{Data Collection and Analysis}

The researchers created an anonymous questionnaire, using both closed- and openended questions. The questionnaire, titled "Foreign Working Mothers and Childrearing," was distributed to potential participants at the beginning of June, and data was collected from June to October 2018 using SNS. To find potential participants for this study, the researchers contacted acquaintances, friends, and the Japan Association for Language Teaching (JALT) Chapters and Special Interest Groups (SIGs) as well as a number of foreign mother groups.

The questionnaire data was automatically compiled on a spreadsheet, as it was administered using the online platform Google Forms. Manual frequency counts were then applied to the quantitative data and the percentages are provided throughout this paper. Qualitative data were also analysed and a number of responses were chosen to represent the different categories the questionnaire addressed.

\section{The Questionnaire}

Section 1 of the questionnaire (see Appendix) was aimed at collecting demographic data. Section 2 collected information about the participants' work lives, and Section 3 focused on the linguistic landscape of their families and children. Section 4 examined their hopes for their children's identity and the multicultural or bicultural activities they exposed their children to. Section 5 looked at the familial and social factors the women were affected by. Section 6 concentrated on the challenges and difficulties they have as foreign working mothers. The questionnaire further investigated how they dealt with these issues and their hopes for Japanese society in the future-how they thought it could become a friendlier environment for foreign working mothers.

Several questions were Likert-type questions using a scale of 1 to 4 . To obtain more authentic and rigorous data, and to avoid respondents selecting a neutral answer, a central option was omitted from the common 1 to 5 scale (Edwards \& Smith, 2014).

All the closed-ended questions in the questionnaire were required questions; however, the questions that were open-ended, requiring longer answers, were optional throughout.

\section{The Pilot Study}

Before launching the official questionnaire, a pilot study was conducted to test the understandability, feasibility, and validity of the questions used. Using the results of the pilot study, along with feedback from the participants, several changes were made to the questionnaire to improve the flow and comprehensibility.

\section{Findings and Discussion}

\section{The Participants}

The questionnaire received 145 responses from working mothers across all parts of Japan. North Americans made up 44.1\%, Oceania 18.6\%, the UK 7.6\%, Europe 5.5\%, the European Union 4.1\%, and other regions (such as Eastern Europe, Central Asia, Africa, and South-East Asia outside of Japan) 7.6\%. The UK was grouped separately from Europe due to the current status of the Brexit negotiations.

Across all the respondents, $8 \%$ claimed to be of Japanese nationality, even though their responses indicated that they were non-Japanese. One possible explanation for this is that they had taken Japanese citizenship, but as the researchers were unable to confirm this, their responses were included in the analysis.

Each respondent was asked to select the amount of time they had been in Japan, but rather than a particular number of years, the questionnaire provided a number of 5 -year bands; each respondent selected the band applicable to them. As result, the data collected do not allow for an accurate calculation of the median and average length of time that the participants have been in Japan. To compensate for this, the researchers assumed a relatively uniform distribution within each 5-year band, allowing for the calculation of the median 5-year and the average 5-year bands. For example, if 29 people selected a length of stay in the band 6-10 years, an average of 8 years (6 years plus 10 years divided by 2) was assumed, and the total years for those 29 people was 232 .

Working across all of the 5-year bands with this assumption, the researchers were able to calculate both an average and median number of years in Japan, from which the average and median 5 -year bands could be determined. The results showed the median 5-year band for the length of time participants have lived in Japan was 11-15 years, and the average band was $16-20$ years.

Participants were an average age of 41.35 years old and the majority (75\%) had a Japanese partner and an average of 1.72 children. 


\section{Study Limitations}

The study has a number of limitations. As it was administered in English, responses were limited only to those proficient in English and excluded other foreign working mothers. Whilst the researchers were pleased with the responses provided by the participants, it would be ideal to conduct the survey in multiple languages so that the study could be more inclusive of a wider range of nationalities.

\section{The Challenges and Difficulties Faced by Foreign Mothers}

As shown in Table 1, the top five challenges and difficulties were stress (71\%), personal time (70.3\%), clashing of school events and working hours (63.4\%), language difficulties (46.9\%), and child illness (39.3\%). Although many of these problems may be faced by many working mothers all around the globe, it is certainly more stressful to be raising a family in a foreign culture where one can be unfamiliar with the culture, customs, and language. Language difficulties was also one of the greatest challenges, and this is something that the respondents would not have faced in their own country. Almost half of the respondents claimed to have language difficulties, and only $19.3 \%$ or 28 respondents said that they had near-native competence in Japanese.

Many mothers also felt that the education system, particularly in the lower years, is not designed to accommodate working women. During a child's elementary years, mothers are required to serve for a period of time on the PTA; however, this places huge demands on a mother who works and may not possess adequate Japanese language skills (Lane, 2017). Furthermore, when schools organize events such as a parent observation day or a sports day, they generally hold them on a weekend so both parents are able to attend. This results in the following Monday being a school holiday and families, particularly mothers, are left with the concern of who will look after the children.

Many of the respondents included comments regarding their difficulties in the Other section of the questionnaire; one mother from the Caribbean who had been in Japan for 6-10 years said, "Japan is a great place to raise children, but they make it so difficult to combine work and being a parent ..." A North American woman who had been in Japan for 16-20 years said, "My head of Dept. is Japanese and a mom. I would've quit without her support, but no other coworkers really get it - more so the foreign guys whom I expect better of. It's hard, stressful and alienating at times being the only foreign fulltime working mom at your place of work." Another North American respondent who has been in Japan for more than 30 years said, "I worked part-time when the kids were in elementary school then full-time when the youngest went into JHS. This delayed my career and now I can't find non-contract full-time work because I am too old. Penalized for taking time to raise the kids."

Table 1. Reported Challenges and Difficulties Faced $(N=145)$

\begin{tabular}{lcc}
\hline Challenges and difficulties reported & Number & Percentage \\
\hline Stress & 103 & $71.0 \%$ \\
Having no personal time for me & 102 & $70.3 \%$ \\
Clashing of school events and working hours & 92 & $63.4 \%$ \\
Language difficulties & 68 & $46.9 \%$ \\
Child illness & 57 & $39.3 \%$ \\
Little time to spend with my family & 49 & $33.8 \%$ \\
Closing of child/children's' class/es due to contagious illness & 38 & $26.2 \%$ \\
Personal illness & 33 & $22.8 \%$ \\
No support from educators with raising my child/children & 28 & $19.3 \%$ \\
bilingually/bicultural & & \\
Racial discrimination & 26 & $17.9 \%$ \\
Power harassment & 23 & $15.9 \%$ \\
Judgmental remarks from non-working mothers & 20 & $29.0 \%$ \\
Sexual discrimination & 18 & $11.7 \%$ \\
Maternity harassment & 17 & $11.7 \%$ \\
No support from colleagues & 17 & $11.7 \%$ \\
Conflicts with parents-in-law and the decision to work & 9 & $6.2 \%$ \\
Sexual harassment & 8 & $5.5 \%$ \\
Having to take care of my elderly parents-in-law & 7 & $4.8 \%$ \\
Having to take care of my elderly parents & 3 & $2.1 \%$ \\
All of the above & 0 & $0 \%$ \\
None of the above & 1 & $0.7 \%$ \\
Other & 0 & $0 \%$ \\
\hline
\end{tabular}

Note. As respondents were able to choose multiple responses, the totals are not $100 \%$. 
In the questionnaire, respondents were asked to describe the tactics they used to deal with the challenges and difficulties they experienced as working foreign mothers. As shown in Table 2, 63.4\% of the respondents selected time management as their most common tactic, $36.6 \%$ said they made sure they had me time, $34.5 \%$ reported that they reduced their working hours, $29.7 \%$ sought parents in a similar situation, and $17.9 \%$ asked their parents-in-law for help.

The women in the study had to fulfil their roles as cultural and linguistic transmitters for their children and handle responsibilities in their professional lives daily. It could be that they recognized that to remain physically and emotionally healthy they had to manage their time as well as possible and find needed personal time whenever possible. Working while raising multicultural children can be new for some women who were raised differently and may be lonely for those who lack the linguistic and cultural understanding of the (Japanese) foreign culture. Reducing their working hours, seeking parents in a similar situation, and asking parents-in-law for help are some ways in which the women could give more to their homes and get support in balancing work and childrearing.

One of the greatest benefits of flexi-time is improving work-life balance, and many working mothers $(67.6 \%)$ who took part in the survey hoped that Japan would offer flexitime in the future. Being able to choose their working hours would allow mothers to pick up their children from school or enable them to be present when they come home from school.

Respondents also hoped that fathers would be allowed to (44.1\%) or encouraged to (66.2\%) take paternity leave. Japan's paternity leave system is ranked the second highest in the developed world, after only South Korea, and under the law fathers are entitled to take 52 weeks of leave with $58.4 \%$ pay (Organisation for Economic Co-operation and Development, 2016). However, Japanese corporate culture requires long working hours, and leave of any kind is not supported or encouraged (Holloway \& Nagase, 2014; Koide, 2015). As a result, only $2 \%$ of Japanese men take paternity leave and they are said to face ridicule, pay cuts, and demotion, or remain in their job without the opportunity of promotion upon return to work. Therefore, despite having a world-class legal status, social norms and expectations effectively disallow fathers' access to this legal right, and the responsibility of child-rearing falls to the mother (McCarthy, 2015).

Many respondents (51\%) also wanted more language support in their native language, especially official letters or notices. This also relates to language difficulties, and although many may have become proficient enough orally to undertake everyday life, reading remains a difficulty.
Table 2. Tactics Reported to Deal With Challenges and Difficulties $(N=145)$

\begin{tabular}{lcc}
\hline Tactics used & Number & Percentage \\
\hline Time management & 92 & $63.4 \%$ \\
Making sure I have me-time & 50 & $36.6 \%$ \\
Reduced my working hours & 43 & $34.5 \%$ \\
Sought parents in a similar situation & 26 & $17.9 \%$ \\
Asked my parents-in-law for help & 26 & $17.9 \%$ \\
Changed jobs & 25 & $17.2 \%$ \\
Parent/s came from abroad to help out & 22 & $15.2 \%$ \\
Took time off for medical treatment for myself & 22 & $15.2 \%$ \\
Took time off for medical treatment for my child/children & 9 & $6.2 \%$ \\
Changed child's/children's day-care & 5 & $3.4 \%$ \\
Had medical treatment in my home country & 7 & $4.8 \%$ \\
Quit my job to take care of my children & 4 & $2.8 \%$ \\
None of the above & 2 & $1.4 \%$ \\
Took time off to care for my parents & 2 & $1.4 \%$ \\
Took time off to care for my parents-in-law & 1 & $0.7 \%$ \\
Quit my job to care for my parents & 0 & $0 \%$ \\
Quit my job to care for my parents-in law & 0 & $0 \%$ \\
All of the above & 0 & $0 \%$ \\
Other & & 0 \\
\hline
\end{tabular}

Note. As respondents were able to choose multiple responses, the totals are not $100 \%$.

Babysitting services were also thought to be lacking by many respondents (49\%), with one North American mother who had been in Japan for 26-30 years even stating that the lack of support and available services in her child's formative years had led to her deciding not to have any more children. 
And of course, equal pay and job responsibilities are definitely something that women, not only in Japan but around the globe, aspire to, although only $56.6 \%$ identified them as an aspiration for the future.

Table 3. Future Aspirations for Japan $(N=145)$

\begin{tabular}{lcc}
\hline Future aspirations & Number & Percentage \\
\hline Flexi-time & 98 & $67.6 \%$ \\
Encourage fathers to take paternity leave & 96 & $66.2 \%$ \\
Equal pay and job responsibilities & 82 & $56.6 \%$ \\
Language support for foreign mothers. e.g. letters/notices & 74 & $51 \%$ \\
written in the mother's native tongue & & \\
Babysitting services & 71 & $49 \%$ \\
No waiting list for childcare & 70 & $48.3 \%$ \\
Allow paternity leave & 64 & $44.1 \%$ \\
Schools scheduling more events on the weekend & 55 & $37.9 \%$ \\
Offer a longer maternity leave & 43 & $29.7 \%$ \\
Creating ways to get working mothers involved in school & 30 & $20.7 \%$ \\
activities & & \\
Not closing classes due to contagious illness & 25 & $17.2 \%$ \\
All of the above & 12 & $8.3 \%$ \\
Other & 0 & $0 \%$ \\
\hline
\end{tabular}

Note. As respondents were able to choose multiple responses, the totals are not $100 \%$.

\section{Future Directions}

A follow-up survey may be conducted to investigate whether the challenges and difficulties of these foreign working mothers changed or improved over time; another is planned to see how foreign working women's challenges and difficulties differed or were similar to those of Japanese women.

\section{Conclusion}

The study provided some understanding of the experiences of foreign working women participating in multicultural child-rearing. The researchers felt they collected useful data that will contribute to the existing literature on foreign maternal employment. The data are also immensely valuable as Japan seeks a more international position, as the Japanese government is saying it is aiming for more women to contribute to the workforce (Chotani, 2017).

The researchers found that foreign working women encountered various challenges while participating in multicultural child-rearing. Although working women in other countries experience challenges in balancing work and family, this is compounded for foreign women in Japan who must maneuver the culture and language in a society that expects women to handle virtually all the duties related to children and home. Results indicated that the women experienced challenges related to stress, lack of personal time, educational issues related to clashing of school events, and as expected, language difficulties. However, in many cases, the women found ways to combat these challenges, including using time management and seeking support from other parents in a similar situation. The women in the study wished for a healthier life in which they could participate in multicultural childrearing and the labor force, through initiatives such as flexi-time, encouragement of paternity leave, and improved childcare services. The women hoped all of these could be improved over time so that Japan could become a more welcoming place for women who want to continue their careers after childbirth. However, many of these problems cannot be changed through governmental laws and policies alone, and a fundamental change in social attitudes and cultural reform is required for any real progress to be made.

\section{Bio Data}

Lauren Landsberry has been in ELT for more than 15 years, holds an MA in applied linguistics from Monash University, and is currently undertaking further study at Macquarie University. She teaches at several universities throughout Nagoya and her interests include bilingualism, world Englishes, SLA, and teacher development. $<$ laurenlandsberry@gmail.com>

Tenesha Kanai has taught in Japan since 2009. She has a master's degree from the University of Bradford and a Cambridge CELTA. Her research interests include mixedrace children in Japan, intercultural parenting, second language acquisition, and bilingualism. <teneshachin@gmail.com> 


\section{References}

Chotani, V. M. (2017, July 30). Five years on, where does Abe's Womenomics stand? Journal of International Affairs. Retrieved from https://jia.sipa.columbia.edu

Edwards, M., \& Smith, B. (2014). The effects of the neutral response option on the extremeness of participant response. Journal of Undergraduate Scholarship, 6. Available from http://blogs. longwood.edu/incite/

E-Stat. (2017). 国籍・地域年齢・男女別在留外国人 [Table of foreigners in Japan showing nationality, age and sex]. Retrieved March 27, 2019, from https://www.e-stat.go.jp/stat-search/files?page $=1 \&$ layout $=$ datalist\&toukei $=00250012 \&$ tstat $=000001018034 \&$ cycle $=1 \&$ year $=20170 \&$ month $=120406$ 06\&tclass $1=000001060399$

Goto, T. (2018, February 27). Japan's moms stay in work in record numbers. Nikkei Asian Review. Retrieved from https://asia.nikkei.com

Holloway S. D., \& Nagase A. (2014). Child rearing in Japan. In H. Selin. (Ed.), Parenting across cultures. Science across cultures: The history of non-western science (vol. 7, pp. 59-76). Dordrecht, Germany: Springer. https://doi.org/10.1007/978-94-007-7503-9_6

Jiji Press. (2018, April 4). More than 55,000 children wait for nursery school places in Japan as lists grow for a third straight year. Japan Times. Retrieved from https://www.japantimes.co.jp/

Jolivet, M. (1997). Japan: The childless society?: The crisis of motherhood. London, England: Routledge.

Koide, T. A. (2015). Achievement of work-life balance: Japanese and foreign mothers in Japan. International Journal of Gender and Women's Studies, 3(2), 28-41.

https://doi.org/10.15640/ijgws.v3n2a4

Kuramoto, M., Koide, T., Yoshida, T., \& Ogawa, E. (2017). Raising multicultural children in Japan: A mixed methods examination of parent-child-society dynamics. Journal of Intercultural Communication Research, 46(4), 360-384. https://doi.org/10.1080/17475759.2017.1355839

Lane, E. (2017, June 2). The young Japanese working themselves to death. BBC World Service. Retrieved from https://www.bbc.com/news/business-39981997

Lewis, L. (2015, July 7). Japan: Women in the workforce. Financial Times. Available from https:// www.ft.com/content/60729d68-20bb-11e5-aa5a-398b2169cf79

McCarthy, N. (2015, August 25). Where do fathers receive the most paternity leave? Forbes. Retrieved from https://www.forbes.com

Organisation for Economic Co-operation and Development. (2016). Key characteristics of parental leave systems. Retrieved from https://www.oecd.org/els/soc/PF2_1_Parental_leave_systems.pdf

Wingfield-Hayes, R. (2013, March 22). Japan: The worst developed country for working mothers? $B B C$ News. Retrieved from https://www.bbc.com/news/magazine-21880124
Yamazaki, Y., Kozono, Y., Mori, R., \& Marui, E. (2011). Difficulties facing physician mothers in Japan. The Tohoku Journal of Experimental Medicine, 225, 203-209.

https://doi.org/10.1089/jwh.2014.4736

Yu, W. (2009). Gendered trajectories: Women, work, and social change in Japan and Taiwan. Stanford, CA: Stanford University Press.

Zhou, Y. (2015). Career interruption of Japanese women: Why is it so hard to balance work and childcare? Japan Labour Review, 12(2), 106-123.

\section{Appendix}

The Questionnaire: Foreign Working Mothers and Child-Rearing

Section 1. Demographics

Age
25 and under
- 26-30
- $31-35$
$36-40$
41-45
- 46-50
- 51-55
- 56-60
- Over 60

Marital status ...You are

- Engaged

- Married

- Widowed

- Separated

- Divorced

- Never married and a single mother

- Other: 
Which region are you from?

- Oceania

- Japan

- South East Asia (outside Japan)

- Africa

Central Asia

- Eastern Europe

- Europe

The European Union

The UK

North America

- Central America

- South America

The Caribbean

- The Middle East

- Other:

How long have you been in Japan?

- 5 years or less

6-10 years

- 11-15 years

16-20 years

- 21-25 years

26-30 years

31-35 years

- 36-40 years

- More than 40 years
In which industry do you work? (If you have more than one job please select your main employment)

- Education

Consulting

Communication

IT

- Healthcare

- Manufacturing

- Public

- Retail

- Service

Other:

Employment Status

- Full-time

- Contracted, and work full-time hours

- Part-time, but work full-time hours

- Part-time; only work a few days or hours per week

- Currently off on maternity leave

- Other:

How many children do you have?

- 1

- 2

- 3

- 4

More than 4 
How old are they? (more than one answer is ok)

- Three and under

- Between three and elementary school

- Elementary school age

- Junior High School age

- Senior High School age

University age

- Adult

\section{Section 2. Work Life}

Please tell us about your work life.

Why did you return to work after having a child/children?

- For financial reasons

I enjoy my career

Both

- Neither

Other:

How do you find balancing family life and a career?

- On a scale of 1-4; Difficult, it's a struggle. - Easy, no problem at all!

Do you feel as though you can excel at both?

- On a scale of 1-4; No, my family hasn't suffered at all - Yes, but at the sacrifice of my family.

Do you feel supported by your co-workers?

- On a scale of 1-4; No - Yes

Do you feel supported by your employer?

- On a scale of 1-4; No - Yes

\section{Section 3. Bilingualism and You}

Please tell us about the linguistic landscape of you and your family.

What languages do you speak at home? (more than one answer is ok)

- Japanese

- Chinese

- Korean

- English

- Spanish

Other:

How would you rate your Japanese language skills?

- On a scale of 1-4; No Japanese - Native-like

What bilingual strategies/approach do you use with your child/children?

- One parent speaks one of the two languages to the child; we follow the one parent one language strategy

- We often mix our languages, everyone is bilingual or multilingual

- Everyone speaks the same language at home other than the community language; we follow the minority language at home strategy

- We separate the languages according to the time and place; we follow the time and place strategy

- We speak a third language as my partner and I have different languages; we follow the lingua franca method

- We speak our second language even though we are not native speakers; we follow the non-native strategy.

Please comment if you feel your child/children have different strengths with their minority language/s. For example, the older sibling is stronger in their minority language/s than the younger sibling/s etc. 


\section{Section 4. Multiculturalism/Biculturalism}

What kind of identity do you hope for your child/children to have?

- Identify as my culture

- Identify as their father's culture

- Identify as both cultures

- Other:

What kind of cultural activities do you expose your child/children to? (more than one answer is ok)

- Minority language classes (on Saturdays or another day)

- Networking with other bilingual and bicultural families

- Frequent trips to your home country

- Use learning materials from your home country or those in your language

Relatives and/or friends visit from overseas

- They Skype, Facetime, talk on the phone etc. with relatives and/or friends overseas

- They watch media content/ listen to music from both cultures

- They read books from both parents' cultures

- They learn manners and behavior for both cultures

We celebrate holidays for both cultures

- All of the above

None of the above

Other:

\section{Section 5. Familial and Social Factors}

Please tell us about your family situation.

My husband/partner is...OR my child's/children's father is...

- Japanese

- The same nationality as me

- Not Japanese and from a different country to me

- Other:
Who cares for your child/children while you are working? (more than one answer is ok)

- Public/private kindergarten (youchien)

- Public/private kindergarten (hoikuen)

- Private authorised day-care

- Private unauthorised day-care

- Grandparents

- School (Elementary, JH, HS)

Are your parents here with you in Japan?

$$
\begin{aligned}
& \text { - Yes } \\
& \text { - No } \\
& \text { - No, they are deceased. }
\end{aligned}
$$

How do they support your child rearing? (more than one answer is ok)

- Babysit

Nurse when sick

Help financially

- Give emotional support

- Give advice

- All of the above

- None of the above

- They are deceased.

- Other:

Are your husband's/partner's OR your child's/children's father's parents in Japan?

- Yes

- No

- No, they are deceased 
How are they supportive in your child-rearing? (more than one answer is ok)

- Babysit

- Nurse when sick

- Help financially

Give emotional support

Give advice

All of the above

- None of the above

- They are deceased, not applicable

Other:

Is your husband/partner OR your child's/children's father supportive with child-rearing?

- On a scale of 1-4; No - Yes

Does your husband/partner OR child's/children's father help with domestic duties?

- On a scale of 1-4; Doesn't help - Helps a lot

\section{Section 6. Challenges and Difficulties}

What are some challenges you have experienced as a foreign working mother in Japan? (more than one answer is ok)

- Having no personal time for me

- Little time to spend with my family

Language difficulties

Stress

- Personal illness

- Child illness

- Clashing of school events and working hours

Closing of child/children's' class/es due to contagious illness

- Judgmental remarks from non-working mothers
- Conflicts with parents-in-law and the decision to work

- Having to take care of my elderly parents

- Having to take care of my elderly parents-in-law

- Maternity harassment

- Power harassment

Racial discrimination

- Sexual harassment

- Sexual discrimination

- No support from colleagues

- No support from educators with raising my child/children bilingually/biculturally

All of the above

- None of the above

- Other:

How have you dealt with these challenges? (more than one answer is ok)

- Time management

Making sure I have me-time

- Asked my parents-in-law for help

- Parent/s came from abroad to help out

- Sought parents in a similar situation

- Took time off for medical treatment for myself

- Took time off for medical treatment for my child/children

- Had medical treatment in my home country

- Quit my job to take care of my children

- Took time off to care for my parents

- Quit my job to care for my parents

- Took time off to care for my parents-in-law

- Quit my job to care for my parents-in law

Changed jobs 
- Reduced my working hours

- Changed child's/children's' day-care

- All of the above

- None of the above

- Other:

How would you like to see Japanese society change to make it easier for foreign working mothers? (more than one answer is ok)

- Flexi-time

- Offer a longer maternity leave

- Allow paternity leave

- Encourage fathers to take paternity leave

- Schools scheduling more events on the weekend

- Not closing classes due to contagious illness

- Creating ways to get working mothers involved in school activities

- Language support for foreign mothers. eg. letters/notices written in the mother's native tongue

- Babysitting services

- No waiting list for childcare

- Equal pay and job responsibilities

- All of the above

- Other:

If you would like to make further comments, please use this section. 